\title{
Toxicity of Hypofractionated Radiotherapy Following Breast Conservative Surgery in Breast Cancer
}

\author{
Aiat Morsy ${ }^{1}$, Sara H. Hammouda ${ }^{2}$, Samir Shehata1, Ali Zedan ${ }^{3}$ \\ ${ }^{1}$ Clinical Oncology and Nuclear Medicine Department, Faculty of Medicine, Assiut University, Assiut, Egypt \\ ${ }^{2}$ Radiotherapy Department, South Egypt Cancer Institute, Assiut University, Assiut, Egypt \\ ${ }^{3}$ Department of Surgical Oncology South Egypt Cancer Institute, Assiut University, Assiut, Egypt \\ Email:^dr_aiat@yahoo.com
}

How to cite this paper: Morsy, A., Hammouda, S.H., Shehata, S. and Zedan, A. (2019) Toxicity of Hypofractionated Radiotherapy Following Breast Conservative Surgery in Breast Cancer. Journal of Cancer Therapy, 10, 371-381.

https://doi.org/10.4236/jct.2019.105031

Received: April 7, 2019

Accepted: May 20, 2019

Published: May 23, 2019

Copyright $\odot 2019$ by author(s) and Scientific Research Publishing Inc. This work is licensed under the Creative Commons Attribution International License (CC BY 4.0).

http://creativecommons.org/licenses/by/4.0/

\begin{abstract}
Background: Adjuvant radiotherapy has increased disease-free and overall survival rates in breast cancer. Conventionally fractionated radiotherapy delivers 50 Gy over 5 weeks which is the standard approach. A shorter duration of hypofractionated radiotherapy (HFRT) will be more convenient for patients and treatment providers if found safe and equally effective. Material and Methods: Fifty-four breast cancer patients who underwent breast conservative surgery (BCS) were enrolled in this study. The patients received $4005 \mathrm{cGy} / 15$ fractions. A boost to the tumor bed was administered in all patients. In this study, radiotherapy induced toxicity was evaluated. Results: In this study, the median age of our patients was 48 years with age ranged from 28 to 69 years. Acute skin toxicity was assessed, and it was noted that grade 2 skin toxicity was shown in only 6 patients $(11.1 \%)$ at the end of radiotherapy and disappeared after 6 weeks of treatment. Late skin toxicity (telangectasia, hyperpigmentation, and subcutaneous fibrosis) was assessed and showed that most patients had grade 0 toxicity with no grade 3 toxicity at all. Regarding pulmonary toxicity, 5 patients $(9.3 \%)$ developed acute pneumonitis and as regards chronic lung toxicity, it was evident in only 3 patients, 2 patients (3.7\%) were grade 1 and 1 patient (1.9\%) was grade 2. Cardiac toxicity was evident in 2 patients (7.1\%) of the left breast cancer patients. Regarding lymphoedema, most patients that showed lymphoedema were grade 1 . Conclusion: The results confirm the safety and feasibility of adjuvant hypofractionated whole breast radiotherapy in breast cancer patients in terms of acute and late toxicity.
\end{abstract}

\section{Keywords}

Breast Cancer, Hypofractionated Radiotherapy, Breast Conservative Surgery, 


\section{Introduction}

Breast cancer is the most common cancer in women worldwide. Based on tumor and patient characteristics, treatment involves a multimodality approach which includes a combination of surgery with or without radiotherapy and/or systemic therapy [1].

Adjuvant radiotherapy improves local control and overall survival, with a 70\% reduction in the risk of recurrence and a $9 \%-12 \%$ reduction in the risk of death. The conventional fractionation regimen is 1.8 - 2 Gy daily fractions for a total dose of 45 to 50 Gy to the whole breast over 5 weeks with or without a boost to the surgical bed [2].

Although there have been concerns that radiotherapy using a daily dose $>2$ Gy/fraction might lead to increased toxicity and impaired cosmesis the interest in hypofractionated radiotherapy was renewed over the last years. Hypofractionated radiotherapy is defined as a larger daily dose delivered often over a shorter period of time. Hypofractionated radiotherapy results in a shorter period of treatment only 2 - 3 weeks compared to conventional radiotherapy that requires 6 - 7 weeks [2].

This will result in reduced costs and waiting patient list and making treatment more acceptable for patients and hence decrease patient psychological morbidity associated with a long treatment course [1].

Also, large multicentric randomized trials with 5 - 10 year follow up data have shown efficacy and safety regarding local control and cosmetic outcome [3] [4]. The first trial was conducted in Canada and has tested 42.5 Gy in 16 fractions against 50 Gy in 25 fractions resulting in equivalent local control and breast cosmesis [3]. The two most recent randomized studies, conducted in UK (Start Trails) have shown that hypofractionated radiotherapy offers favorable late effects and locoregional tumor control rates [3] [5].

Data concerning acute and late radiation-related toxicities are now mature [6] [7]. However, inspite significant data and support of hypofractionated radiotherapy it's not yet being used extensively worldwide [1].

The aim of this study was to assess the acute and late toxicity of adjuvant hypofractionated whole breast radiotherapy in breast cancer patients.

\section{Patients and Methods}

\subsection{Characteristics of Patients and Data Collection}

This retrospective study was carried out between January 2010 and December 2014 at the radiotherapy department in south Egypt cancer institute, Assiut University, Assiut, Egypt. This study was approved by the ethics committee in our faculty. 
All patients included in this study had the following criteria: Female gender, age between 18 and 70 years of age, all patients had histopathologically proven carcinoma of the breast with pT1, pT2, N0-N1 according to the AJCC Cancer Staging Manual 7th ed.and after breast conservative surgery.

Patients were excluded from this study in case of age above 70 years or mastectomized or inoperable tumor or metastatic disease.

\subsection{Treatment}

54 patients were included in this study. Patients were treated with linear accelerator using $6 \mathrm{MV}$ photon beam to a dose of $4005 \mathrm{cGy} / 15$ fractions. Radiotherapy was delivered with lateral and medial tangential fields, using $6 \mathrm{MV}$ photon beam $3 \mathrm{D}$ planning. All patients received an additional electron tumor bed boost of $1000 \mathrm{cGy} / 5$ fractions.

\subsection{Follow Up}

Acute skin toxicity was assessed daily during treatment then weekly for 6 weeks after finishing radiotherapy, graded based on the Radiation Therapy Oncology Group (RTOG) acute toxicity scale.

Late skin toxicities (telangiectasia, hyperpigmentation and subcutaneous fibrosis) were assessed at 12 mons and 24 mons of finishing radiotherapy and were graded using the RTOG/EORTC late radiation morbidity scoring scheme.

Pulmonary toxicities: All patients were evaluated by chest X-ray very 3 mons for the first year and every 6 months thereafter. CT chest was carried out for symptomatic patients with negative chest X-ray. Acute pulmonary toxicities were graded according to RTOG acute radiation lung morbidity scoring criteria. Chronic lung toxicities were scored using the RTOG/EORTC late radiation morbidity scoring scheme [8] [9].

Cardiac toxicities: Left sided patients were assessed by echocardiography before starting treatment and at three months after finishing the treatment. Fall of more than $10 \%$ ejection fraction $(\mathrm{EF})$ is considered significant.

Lymphedema: All patients were assessed for ipsilateral arm lymphedema by monitoring the arm circumference on both sides before radiation treatment and at 3,12 , and 24 months after radiation treatment.

\subsection{Statistical Analysis}

Data analysis was done with the help of SPSS version 22 software which included descriptive analysis. Mean was calculated for a quantitative variable like age. X2 test was used to compare acute and late toxicity between different sample groups and to analyze the association between toxicity with clinical characteristics. $\mathrm{P}$ value below 0.05 was considered significant.

\section{Results}

Our observational retrospective study included 54 patients with breast cancer 
who underwent breast conservative surgery. All of our patients received adjuvant hypofractionated radiotherapy. Those patients attended to the radiotherapy department of South Egypt cancer institute (SECI), Assiut University, Egypt, between January 2010 till December 2014 (Table 1, Table 2).

\section{Acute Radiation Skin Toxicity}

Graded according to the RTOG acute radiation morbidity scoring criteria 2000 (Table 3 and Figure 1).

Factors that may affect the grade and the incidence of acute radiation skin toxicity were studied and there were no significant differences ( $\mathrm{P}$-value $>0.05$ ) as shown in Table 4.

Late toxicity graded using the RTOG/EORTC Late radiation morbidity scoring schema 2000 (Tables 5-10 and Figures 2-6).

Table 1. Patient's characteristics.

\begin{tabular}{|c|c|c|}
\hline Variable & No. & $\%$ \\
\hline \multicolumn{3}{|l|}{ 1) Age at Time of Diagnosis: } \\
\hline Range & $28-69$ years. & \\
\hline Median & 48 years. & \\
\hline \multicolumn{3}{|l|}{ 2) Laterality: } \\
\hline RT Side & 26 & $48.1 \%$ \\
\hline LT Side & 28 & $51.9 \%$ \\
\hline \multicolumn{3}{|l|}{ 3) Quadrant Site } \\
\hline UO (Upper Outer) & 26 & $48.1 \%$ \\
\hline UI (Upper Inner) & 7 & $13 \%$ \\
\hline LO (Lower Outer) & 11 & $20.4 \%$ \\
\hline LI (Lower Inner) & 6 & $11.1 \%$ \\
\hline CE (Central) & 4 & $7.4 \%$ \\
\hline \multicolumn{3}{|l|}{ 4) Tumor Grade } \\
\hline Grade 1 & 2 & $3.7 \%$ \\
\hline Grade 2 & 43 & $79.6 \%$ \\
\hline Grade 3 & 9 & $16.7 \%$ \\
\hline \multicolumn{3}{|l|}{ 5) Tumor Histopathology } \\
\hline IDC (Infiltrating Ductal Carcinoma) & 52 & $96.3 \%$ \\
\hline ILC (Infiltrating Lobular Carcinoma) & 2 & $3.7 \%$ \\
\hline \multicolumn{3}{|l|}{ 6) T Stage: } \\
\hline $\mathrm{T} 1$ & 14 & $26 \%$ \\
\hline $\mathrm{T} 2$ & 40 & $74 \%$ \\
\hline \multicolumn{3}{|l|}{ 7) Node Stage: } \\
\hline N0 & 22 & $40.7 \%$ \\
\hline $\mathrm{N} 1$ & 32 & $59.3 \%$ \\
\hline \multicolumn{3}{|l|}{ 8) Hormonal Receptors: } \\
\hline Positive ER and/or PR & 39 & $72.22 \%$ \\
\hline Negative ER and/or PR & 15 & $27.78 \%$ \\
\hline \multicolumn{3}{|l|}{ 9) Her 2 New Over-Expression: } \\
\hline No & 44 & $81.5 \%$ \\
\hline Yes & 10 & $18.5 \%$ \\
\hline
\end{tabular}


Table 2. Treatment characteristics.

\begin{tabular}{ccc}
\hline Variable & No. & $\%$ \\
\hline 1) Chemotherapy & & \\
FAC & 9 & $16.7 \%$ \\
FEC & 21 & $38.9 \%$ \\
AC-Taxol & 22 & $40.7 \%$ \\
CMF & 2 & $3.7 \%$ \\
\hline 2) Radiotherapy & & \\
4005 cGy/15 Fraction & 54 & $100 \%$ \\
\hline 3) Hormonal therapy & & $16.7 \%$ \\
TAM & 9 & $40.7 \%$ \\
AI & 22 & $14.8 \%$ \\
Switched from TAM to AI & 8 & $27.8 \%$ \\
\hline Not Received Hormonal Therapy & 15 & \\
\hline
\end{tabular}

Table 3. Incidence and grades of acute radiation skin toxicity.

\begin{tabular}{lccccc}
\hline & $\begin{array}{c}\text { Grade 0 } \\
\text { No (\%) }\end{array}$ & $\begin{array}{l}\text { Grade 1 } \\
\text { No (\%) }\end{array}$ & $\begin{array}{l}\text { Grade 2 } \\
\text { No (\%) }\end{array}$ & $\begin{array}{l}\text { Grade 3 } \\
\text { No (\%) }\end{array}$ & P-value \\
\hline $\begin{array}{l}\text { 1) At the End of } \\
\text { Radiotherapy }\end{array}$ & $30(55.6 \%)$ & $18(33.3 \%)$ & $6(11.1 \%)$ & $0(0 \%)$ & \\
$\begin{array}{l}\text { 2) After 6 Weeks of } \\
\text { Radiotherapy }\end{array}$ & $45(83.3 \%)$ & $9(16.7 \%)$ & $0(0 \%)$ & $0(0 \%)$ & $\mathrm{P}<0.01^{\star}$ \\
\hline
\end{tabular}

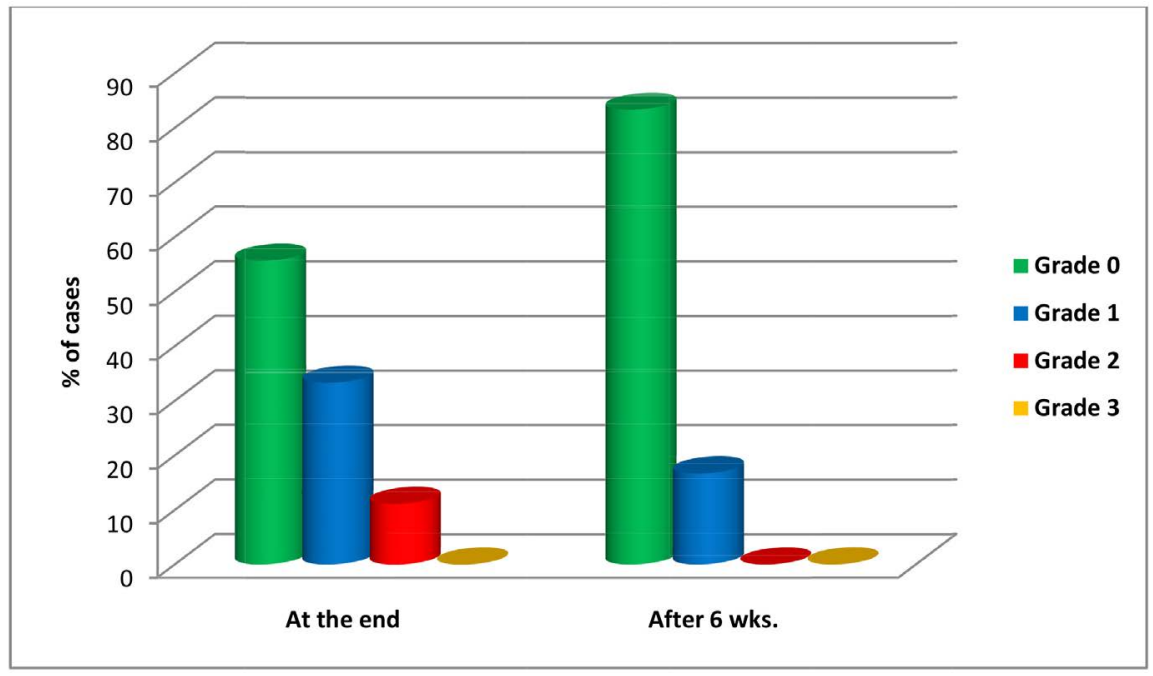

Figure 1. Incidence and grades of acute radiation skin toxicity.

\section{Discussion}

Over the past decade, growing evidence has accumulated that adjuvant HF-RT is not inferior to post-operative conventional radiotherapy in early breast cancer patients. This has been confirmed by the Canadian [10] and the Standardization of Breast Radiotherapy (START) trials [5] [6] and results support the idea 
Table 4. Prognostic factors that may affect incidence and grade of acute radiation skin toxicity reported at the end of radiotherapy.

\begin{tabular}{|c|c|c|c|}
\hline Variable & $\begin{array}{l}\text { Grade } 0 \\
\text { No (\%) }\end{array}$ & $\begin{array}{c}\text { Grade } 1 \text { - } 2 \\
\text { No (\%) }\end{array}$ & $P$ value \\
\hline \multicolumn{4}{|c|}{ Age at Diagnosis } \\
\hline$<55$ Yrs $(31)$ & $17(54.9 \%)$ & $14(45.1 \%)$ & \multirow{2}{*}{0.351} \\
\hline$\geq 55$ Yrs (23) & $13(56.6 \%)$ & $10(43.4 \%)$ & \\
\hline \multicolumn{4}{|l|}{ Laterality } \\
\hline Rt. Side (26) & $15(57.5 \%)$ & $11(42.5 \%)$ & \multirow{2}{*}{0.377} \\
\hline Lt. Side (28) & $15(53.57 \%)$ & $13(46.43 \%)$ & \\
\hline \multicolumn{4}{|l|}{ T Stage } \\
\hline $\mathrm{T} 1$ (14) & $9(64.9 \%)$ & $5(35.1 \%)$ & \multirow{2}{*}{0.231} \\
\hline T2 (40) & $21(52.5 \%)$ & $19(47.5 \%)$ & \\
\hline \multicolumn{4}{|l|}{ Nodal Stage } \\
\hline N0 (19) & $12(63.16 \%)$ & $7(36.84 \%)$ & \multirow{2}{*}{0.406} \\
\hline N1 (35) & $18(51.43 \%)$ & $17(48.57 \%)$ & \\
\hline \multicolumn{4}{|c|}{ Hormonaltherapy } \\
\hline Yes (39) & $23(58.97 \%)$ & $16(41.03 \%)$ & \multirow{2}{*}{0.261} \\
\hline No (15) & $7(46.7 \%)$ & $8(53.3 \%)$ & \\
\hline
\end{tabular}

Table 5. Incidence and grades of telangiectasia.

\begin{tabular}{lccccc}
\hline & $\begin{array}{c}\text { Grade 0 } \\
\text { No (\%) }\end{array}$ & $\begin{array}{l}\text { Grade 1 } \\
\text { No (\%) }\end{array}$ & $\begin{array}{l}\text { Grade 2 } \\
\text { No (\%) }\end{array}$ & $\begin{array}{l}\text { Grade 3 } \\
\text { No (\%) }\end{array}$ & P-value \\
\hline $\begin{array}{l}\text { 1) At 12 Months of } \\
\text { Radiotherapy }\end{array}$ & $39(72.2 \%)$ & $11(20.4 \%)$ & $4(7.4 \%)$ & $0(0 \%)$ & P = 0.386n.s \\
$\begin{array}{l}\text { 2) At 24 Months of } \\
\text { Radiotherapy }\end{array}$ & $37(68.5 \%)$ & $12(22.2 \%)$ & $5(9.2 \%)$ & $0(0 \%)$ & \\
\hline
\end{tabular}

Table 6. Incidence and grades of hyperpigmentation.

\begin{tabular}{lccccc}
\hline & $\begin{array}{c}\text { Grade 0 } \\
\text { No (\%) }\end{array}$ & $\begin{array}{l}\text { Grade 1 } \\
\text { No (\%) }\end{array}$ & $\begin{array}{l}\text { Grade 2 } \\
\text { No (\%) }\end{array}$ & $\begin{array}{l}\text { Grade 3 } \\
\text { No (\%) }\end{array}$ & P-value \\
\hline $\begin{array}{l}\text { 1) At 12 Months of } \\
\text { Radiotherapy }\end{array}$ & $48(88.9 \%)$ & $5(9.2 \%)$ & $1(1.9 \%)$ & $0(0 \%)$ & \\
$\begin{array}{l}\text { 2) At 24 Months of } \\
\text { Radiotherapy }\end{array}$ & $51(94.4 \%)$ & $3(5.6 \%)$ & $0(0 \%)$ & $0(0 \%)$ & \\
\hline
\end{tabular}

Table 7. Incidence and grades of subcutaneous fibrosis.

\begin{tabular}{lccccc}
\hline & $\begin{array}{c}\text { Grade 0 } \\
\text { No (\%) }\end{array}$ & $\begin{array}{l}\text { Grade 1 } \\
\text { No (\%) }\end{array}$ & $\begin{array}{l}\text { Grade 2 } \\
\text { No (\%) }\end{array}$ & $\begin{array}{l}\text { Grade 3 } \\
\text { No (\%) }\end{array}$ & P-value \\
\hline $\begin{array}{l}\text { 1) At 12 Months of } \\
\text { Radiotherapy }\end{array}$ & $43(79.6 \%)$ & $9(16.7 \%)$ & $2(3.7 \%)$ & $0(0 \%)$ & \\
$\begin{array}{l}\text { 2) At 24 Months of } \\
\text { Radiotherapy }\end{array}$ & $45(83.3 \%)$ & $9(16.7 \%)$ & $0(0 \%)$ & $0(0 \%)$ & P = 0.785n.s \\
\hline
\end{tabular}


Table 8. Incidence and grades of acute and chronic lung toxicity.

\begin{tabular}{lccccc}
\hline & $\begin{array}{c}\text { Grade 0 } \\
\text { No (\%) }\end{array}$ & $\begin{array}{l}\text { Grade 1 } \\
\text { No (\%) }\end{array}$ & $\begin{array}{l}\text { Grade 2 } \\
\text { No (\%) }\end{array}$ & $\begin{array}{l}\text { Grade 3 } \\
\text { No (\%) }\end{array}$ & P-value \\
\hline 1) Acute Lung Toxicity & $49(90.7 \%)$ & $3(5.6 \%)$ & $2(3.7 \%)$ & $0(0 \%)$ & P $=0.485 \mathrm{n} . \mathrm{s}$ \\
2) Chronic Lung Toxicity & $51(94.4 \%)$ & $2(3.7 \%)$ & $1(1.9 \%)$ & $0(0 \%)$ & \\
\hline
\end{tabular}

Table 9. Incidence of Cardiac toxicity in left-sided breast cancer patients.

\begin{tabular}{ccc}
\hline Cardiac Toxicity & No & Yes \\
\hline Total Patients $(28)$ & $26(92.9 \%)$ & $2(7.1 \%)$ \\
\hline
\end{tabular}

Table 10. Incidence and grades of lymphedema.

\begin{tabular}{cccc}
\hline Lymphedema & $\begin{array}{c}\text { Grade 0 } \\
\text { No. (\%) }\end{array}$ & $\begin{array}{c}\text { Grade 1 } \\
\text { No. (\%) }\end{array}$ & $\begin{array}{c}\text { Grade 2 } \\
\text { No. (\%) }\end{array}$ \\
\hline Before Irradiation & $49(90.7 \%)$ & $5(9.3 \%)$ & $0(0 \%)$ \\
At 3 Months FU & $44(81.5 \%)$ & $7(13 \%)$ & $3(5.5 \%)$ \\
At 12 Months FU & $42(77.8 \%)$ & $8(14.8 \%)$ & $4(7.4 \%)$ \\
At 24 Months FU & $39(72.2 \%)$ & $10(18.5 \%)$ & $4(7.4 \%)$
\end{tabular}

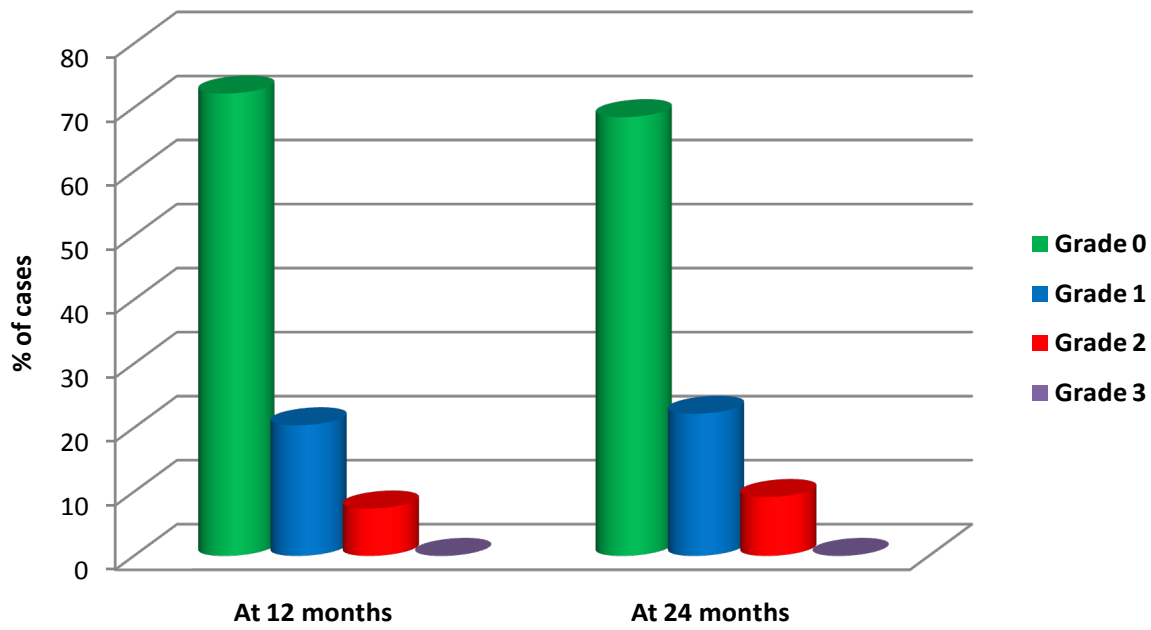

Figure 2. Incidence and grades of telangiectasia.

that hypofractionation is feasible in women with operable T1-3N0-1M0 invasive breast cancer. All hypofractionated schedules-3 Gy/fr up to $39 \mathrm{~Gy} ; 3.3 \mathrm{~Gy} / \mathrm{fr}$ up to $42.9 \mathrm{~Gy} ; 3.2 \mathrm{~Gy} / \mathrm{fr}$ up to $41.6 \mathrm{~Gy} ; 2.66 \mathrm{~Gy} / \mathrm{fr}$ up to $40 \mathrm{~Gy} ; 2.65 \mathrm{~Gy} / \mathrm{fr}$ up to 42.5-showed equivalent clinical outcomes, as well as slightly better cosmetic results compared to conventional radiotherapy. HF-RT using 40 Gy with 2.66 Gy single fractions resulted in the lowest local-regional relapse at 10 years (4.3\%) and in the best breast cosmesis [7]. Since the long-term results of these large randomized clinical trials, the use of HF-RT in early breast cancer has been increasing worldwide [1].

The most common change in breast appearance after radiotherapy is shrinkage, edema, retraction and, teleangectasia. The persistent tissue induration for 


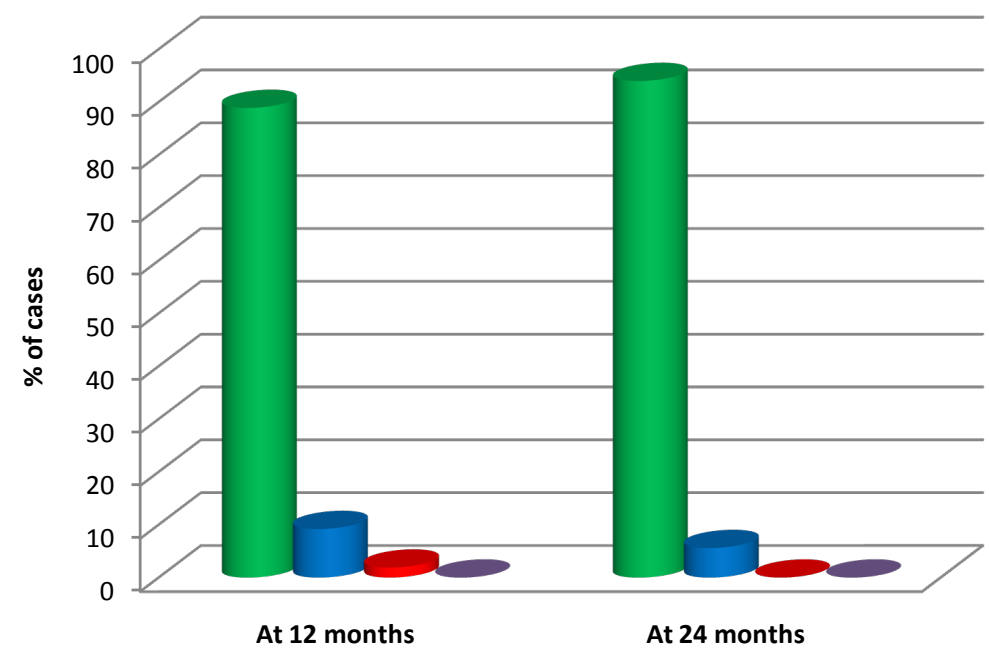

- Grade 0

- Grade 1

- Grade 2

- Grade 3

Figure 3. Incidence and grades of hyperpigmentation.

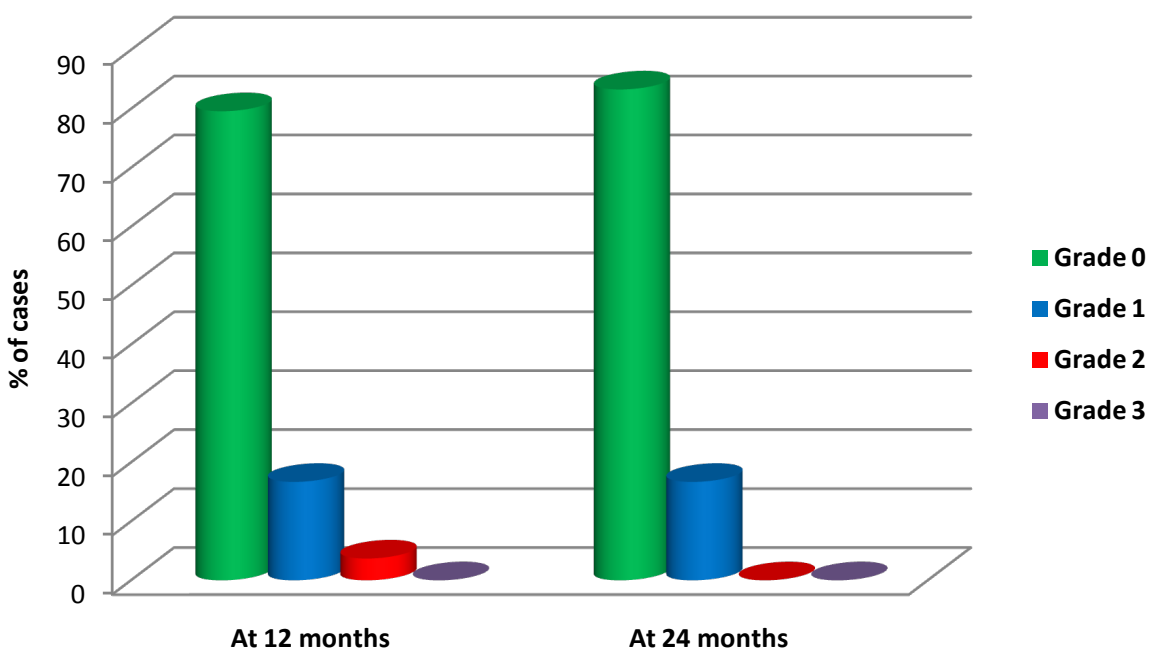

Figure 4. Incidence and grades of subcutaneous fibrosis.

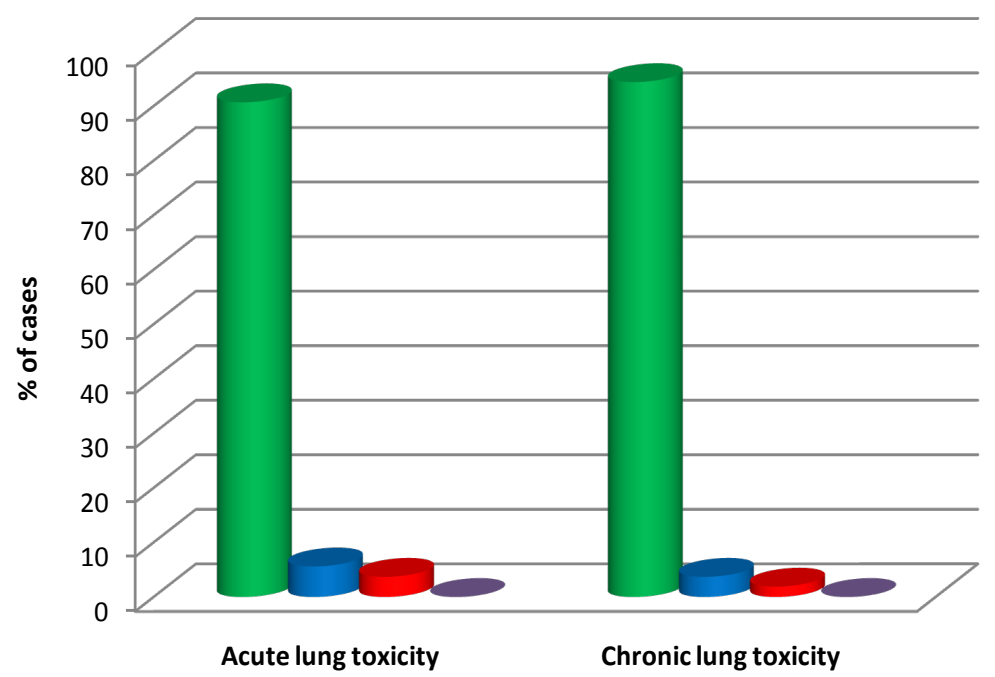

Grade 0

- Grade 1

Grade 2

- Grade 3

Figure 5. Incidence and grades of acute and chronic lung toxicity. 


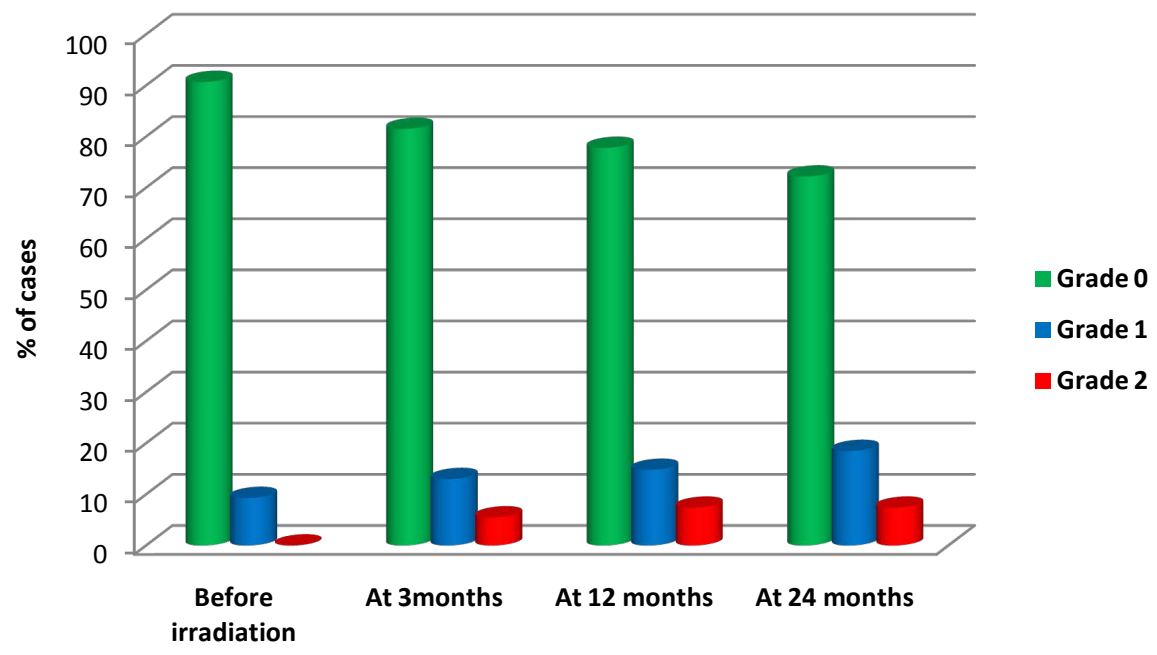

Figure 6. Incidence and grades of lymphedema.

many years after radiotherapy is usually due to an underlying fibrosis, but in the early years, the fat necrosis and breast edema can contribute to induration scores. The adverse effects will appear for as long as patients are alive and the median follow-up times of the hypofractionated trials varied from 5.1 and 9.7 years [2]. The important question, as analyzed by Yarnold and colleagues [11], is whether the fractionation sensitivity of responses developing at the time of reporting are representative of those developing over the entire life span of a patient. Curran et al. showed that the cosmetic outcome after breast-conserving therapy was worse if patients who were followed up much longer than 5 years. On the contrary, the UK Royal Marsden Hospital/Gloucestershire Oncology Centre (RMH/GOC) trial [12] did not show a difference between 5-year and 10-year late adverse effects. As a result of these considerations and uncertainties, nowadays may be unjustified to consider follow-up a factor limiting the interpretation of current hypofractionation trials [13]. In our study the median follow up period was 24 mons ranging from 13 to 36 mons and the study showed that regarding late skin and subcutaneous toxicity, the number of patients showing hyperpigmentation decreased with time but there was an increase in number of patients showing telangectasia, on the other hand, subcutaneous fibrosis slightly improved and finally the number of patients showing lymphoedema increased with time but a longer follow up period is needed to establish clear results.

The question of HF-RT appropriateness when a tumor bed boost is indicated is still controversial. In our series, all patients received a tumor bed boost. Considering that there were no worst skin toxic effects, the boost dose of 10 Gy (2 Gy/fr) in conjunction with HF-RT appeared reasonable. Tumor bed boost of 10 Gy (2 Gy/fr) was optional in START trials, whereas it was not used in Canadian trial [3] [5] [8]. In total, 3,190 patients who were recruited into the START-A (n $=1152 ; 61 \%)$ and START-B $(\mathrm{n}=2038,43 \%)$ trials had tumor bed boost RT. Although a direct comparison of results is unwise due to different patients populations, an unplanned subgroup meta-analysis found that boost irradiation of the 
tumor bed had no harmful effect on both local relapse and normal tissue effects comparing HF-RT versus C-RT [7]. A recent phase II trial tested a lumpectomy bed boost in 4 fractions of 3.33 Gy delivered after a short course of HF-RT to the whole breast (49.95 Gy; 3.33 Gy/fr) [12]. This fractionation scheme appeared to be safe and resulted in excellent local control and cosmetic outcomes. Similarly, the Lyon clinical trial was to evaluate the impact of boost dose following HF-RT (50 Gy; $2.5 \mathrm{~Gy} / \mathrm{fr}$ ). Results showed that a $10 \mathrm{~Gy}$ electron boost (2.5 Gy/fr) to the tumor bed significantly resulted in reduced risk of tumor recurrence, without differences in cosmetic outcome. But the median follow-up (3.3 years) was relatively short and the HF-RT scheme was higher than those used in Canadian and START trials to perform an optimal toxicity profile comparison. Therefore, firm conclusions cannot be drawn, and more proof are required before it's possible to definitively standardize the best HF-RT boost dose per fraction [1].

In our study compliance with hypofractionated radiotherapy after breast conservative surgery was excellent thanks to short treatment duration. The overall objective cosmetic outcome was generally good with satisfactory cosmetic results in nearly $90 \%$ of patient and patient's judgment of their own cosmetic outcomes revealed similar findings. Also, this study showed very good results as only a very small number of patients showed pulmonary and cardiac toxicity which proves that HFRT is a good choice of treatment.

\section{Conclusion}

It is concluded from this study that hypofractionated radiotherapy is a simple and safe treatment protocol for breast cancer patients after breast conservative surgery. There was grade 0 toxicity in most patients and no grade 3 toxicity at all. After the availability of data from international studies hypofractionated radiotherapy should be used as standard treatment as its resource saving with acceptable toxicity.

\section{Conflicts of Interest}

The authors declare no conflicts of interest regarding the publication of this paper.

\section{References}

[1] De Felice, F., Ranalli, T., Musio, D., Lisi, R., Rea, F., Caiazzo, R. and Tombolini, V. (2017) Relation between Hypofractionated Radiotherapy, Toxicity and Outcome in Early Breast Cancer. The Breast Journal, 23, 563-568. https://doi.org/10.1111/tbj.12792

[2] Ciammella, P., Podgornii, A., Galeandro, M., Micera, R., Ramundo, D., Palmieri, T., Cagni, E. and Iotti, C. (2014) Toxicity and Cosmetic Outcome of Hypofractionated Whole-Breast Radiotherapy: Predictive Clinical and Dosimetric Factors. Radiation Oncology, 9, Article ID: 3548. https://doi.org/10.1186/1748-717X-9-97

[3] START Trialists' Group (2008) The UK Standardisation of Breast Radiotherapy (START) Trial A of radiotherapy Hypofractionation for Treatment of Early Breast 
Cancer: A Randomised Trial. The Lancet Oncology, 9, 331-341. https://doi.org/10.1016/S1470-2045(08)70077-9

[4] Whelan, T.J., Kim, D.H. and Sussman, J. (2008) Clinical Experience Using Hypofractionated Radiation Schedules in Breast Cancer. Seminars in Radiation Oncology, 18, 257-264. https://doi.org/10.1016/j.semradonc.2008.04.008

[5] START Trialists' Group (2008) The UK Standardisation of Breast Radiotherapy (START) Trial B of Radiotherapy Hypofractionation for Treatment of Early Breast Cancer: A Randomised Trial. The Lancet, 371, 1098-1107. https://doi.org/10.1016/S0140-6736(08)60348-7

[6] Owen, J.R., Ashton, A., Bliss, J.M., et al. (2006) Effect of Radiotherapy Fraction Size on Tumour Control in Patients with Early-Stage Breast Cancer after Local Tumour Excision: Long-Term Results of a Randomised Trial. The Lancet Oncology, 7, 467-471. https://doi.org/10.1016/S1470-2045(06)70699-4

[7] START Trialists' Group (2013) The UK Standardisation of Breast Radiotherapy (START) Trials of Radiotherapy Hypofractionation for Treatment of Early Breast Cancer: 10- Year Follow-Up Results of Two Randomised Controlled Trials. The Lancet Oncology, 14, 1086-1094. https://doi.org/10.1016/S1470-2045(13)70386-3

[8] Radiation Therapy Oncology Group: RTOG Acute Radiation Morbidity Scoring Criteria 2000.

[9] Radiation Therapy Oncology Group (2000) RTOG/EORTC Late Radiation Morbidity scoring Schema.

[10] Whelan, T.J., Pignol, J.P., Levine, M.N., et al. (2010) Long-Term Results of Hypofractionated Radiation Therapy for Breast Cancer. The New England Journal of Medicine, 362, 513-520. https://doi.org/10.1056/NEJMoa0906260

[11] Yarnold, J., Bentzen, S.M., Coles, C. and Haviland, J. (2011) Hypofractionated Whole-Breast Radiotherapy for Women with Early Breast Cancer: Myths and Realities. International Journal of Radiation Oncology, Biology, Physics, 79, 1-9. https://doi.org/10.1016/j.ijrobp.2010.08.035

[12] Yarnold, J., Ashton, A., Bliss, J., Homewood, J., Harper, C., Hanson, J., Haviland, J., Bentzen, S. and Owen, R. (2005) Fractionation Sensitivity and Dose Response of Late Adverse Effects in the Breast after Radiotherapy for Early Breast Cancer: Long-Term Results of a Randomised Trial. Radiotherapy and Oncology, 75, 9-17. https://doi.org/10.1016/j.radonc.2005.01.005

[13] Bartelink, H. and Arriagada, R. (2008) Hypofractionation in Radiotherapy for Breast Cancer. The Lancet, 371, 1050-1052. https://doi.org/10.1016/S0140-6736(08)60349-9

[14] Ahlawat, S., Haffty, B.G., Goyal, S., et al. (2016) Short-Course Hypofractionated Radiation Therapy with Boost in Women with Stages 0 to IIIa Breast Cancer: A Phase 2 Trial. International Journal of Radiation Oncology, Biology, Physics, 94, 118-125. https://doi.org/10.1016/j.ijrobp.2015.09.011 